\title{
Encoding of Text Reuse in the Project Beta mașāḥəft
}

Daria Elagina

\section{(2) OpenEdition}

Journals

Electronic version

URL: https://journals.openedition.org/jtei/3763

DOI: 10.4000/jtei.3763

ISSN: 2162-5603

\section{Publisher}

TEl Consortium

\section{Electronic reference}

Daria Elagina, "Encoding of Text Reuse in the Project Beta mașāhəft", Journal of the Text Encoding Initiative [Online], Rolling Issue, Online since 22 January 2022, connection on 14 January 2023. URL http://journals.openedition.org/jtei/3763 ; DOI: https://doi.org/10.4000/jtei.3763

For this publication a Creative Commons Attribution 4.0 International license has been granted by the author(s) who retain full copyright. 


\title{
Encoding of Text Reuse in the Project Beta mașāhoft
}

\author{
Daria Elagina
}

\section{ABSTRACT}

The paper discusses the phenomenon of text reuse in the manuscript tradition of Ethiopia and Eritrea and, by examining examples of different forms of text reuse, presents the possibilities of its encoding in TEI XML within the frame of the project Beta mașāhoft. Text reuse, which consists in the implicit or explicit repetition of text, is attested in a variety of forms, including quotations, allusions, paraphrases, and cross-linguistic text reuse. The documentation of this practice contributes to the study of different aspects of the manuscript tradition, for example, to the impact and relative dating of texts, and history of their transmission. The variety of text reuse forms allows for different approaches to their encoding which are presented in this paper 
to illustrate the possibilities of text reuse markup within the project's schema. Additionally, the paper discusses the concept of narrative units and its difference to the concept of text reuse, as well as the markup of a type of text reuse which involves the reference to external entities.

\section{INDEX}

Keywords: Ethiopian Studies, text reuse, digital edition, text encoding, narrative units

\section{Introduction}

1 The literary tradition of Ethiopia and Eritrea incorporates an important aspect of text reuse, that is an implicit or explicit repetition of text or, according to John Lee "the transformation of a source text into a target text in order to serve different purpose" (Lee 2007, 472). Under the term text reuse one understands not a circulation of the same piece of text independently or inside collections of texts, but an incorporation and integration of a particular text (source text) or a portion of it into a newly created one (target/recipient text). Text reuse can take various forms and can be basically divided into two main types: syntactic text reuse - for example, quotations - and semantic text reuse - for example, allusions, paraphrases (G. Franzini, E. Franzini and Büchler 2016). Translations or transliterations are forms of cross-linguistic text reuse. The detection of passages which quote or refer to other texts (borrowed material) is a challenge, especially if the text reuse takes an implicit form and is not signalized in the recipient text. However, the detection of text reuse and the establishment of relations between the source text and the recipient text would contribute to the study of the literary tradition of Ethiopia and Eritrea, especially to the fields of textual criticism, source criticism, the study of intertextuality ${ }^{1}$ and others. For example, the detection of quotations, allusions, and translations of a given text is crucial in textual criticism because these phenomena represent the so-called indirect transmission and might contribute to the understanding of the history of text transmission in general. The identification of quotations might provide data for at least the relative dating of a quoted literary work. Additionally, the study of text reuse and the relations between the source texts and the recipient texts could provide data for an analysis of the impact and quotability of specific texts in Ethiopian and Eritrean manuscript culture. In other words, a massive involvement of a text as a source for text reuse into literary production could 
well document a perception of this text as a reliable and, thus, quotable source of information and consequently illustrate its specific impact on the literary and epistemological tradition, as well as the level and scope of its distribution.

\section{Objectives}

2 In this paper I would like to present several different cases of encoding of text reuse in the project "Beta mașāhoft" ${ }^{2}$ and discuss, based on these examples, the approach to the encoding, its challenges, and limitations, as well as some models for the future encoding strategy. ${ }^{3}$ The examples presented below may serve as proposals for the encoding of text reuse, which has not yet been strictly determined in the project's Guidelines, although the technical possibilities discussed in the paper have already been documented there (Liuzzo et al. 2018). ${ }^{4}$ The paper focuses on the conceptual understanding of different forms of text reuse, the structured application of existing encoding methods, and on providing via practical examples of text reuse encoding that is applicable in other contexts outside the project from which the examples have been taken. The attempt has also been made to approach the differences between the encoding of text reuse and other instances of parallel text transmissions. The purpose being to address the problem in this paper rather than merely document the established and exhaustive methods of markup. The encoding of text reuse can be split into three main aspects: the markup of borrowed material, encoding of relations between the source text and the recipient text, and the markup of elements that signalize the presence of text reuse (Berti et al. 2015, 2). The focus here is mainly on the first two aspects, that is, the markup of borrowed material and the markup of relations. The markup of borrowed material using <div type="textpart" $>$ s in the recipient text is applicable if a precise identification of a string of a reused text is possible and if the introduction of these $<$ div type=" textpart ">s does not cause a conflict of overlapping hierarchies ${ }^{5}$ with other $<$ div type="textpart" $>$ s of the text. Otherwise, a relation can be ascribed to a longer $<$ div type=" textpart" $>$ without a precise specification of the string. The relations between the source and the recipient texts can be established if the source text is identifiable, using for example a $<$ relation name=" saws : hasUsed" $>^{6}$ with a possible precise explanation of the type of text reuse in $a<$ desc $>$ element. This relation does not presuppose the type or the scale of text reuse and thus applicable to almost any case of the encoding of borrowed material in the text. 


\section{Encoding of Relations}

4 A good example of the strategy of encoding of text reuse with $<$ relation name=" saws : hasUsed" $>$ is the case of Mașhafa madbal (CAe 5188), ${ }^{7}$ an Ethiopic literary work consisting of paraphrases in verses of the Bible and its Apocrypha (Wright 1877, 285a-286a). The work is divided into two main parts, the first, Mośțira zaman bəluy, is a paraphrase of the Old Testament (CAe 3530) and its Apocrypha and the second, Mośtira zaman haddis, a paraphrase of the New Testament $(\mathrm{CAe} 2072)^{9}$ and its Apocrypha. Aside from the reused material both parts contain introductions in prose which seem not to be based on borrowed material. The relations between the recipient and source texts, the old Testament, and the New Testament, can then be encoded as follows, whereMașhafa madbal contains two <div>s, the first one <div type="textpart" subtype="part" xml:lang="gez" xml:id="PartI" > for Məśtira zaman bəluy, and the second one <div type="textpart" subtype="part" xml: lang="gez" xml:id="PartII"> for Mośțira zaman haddis:

Example 1. Use of <relation name=" saws : hasUsed">

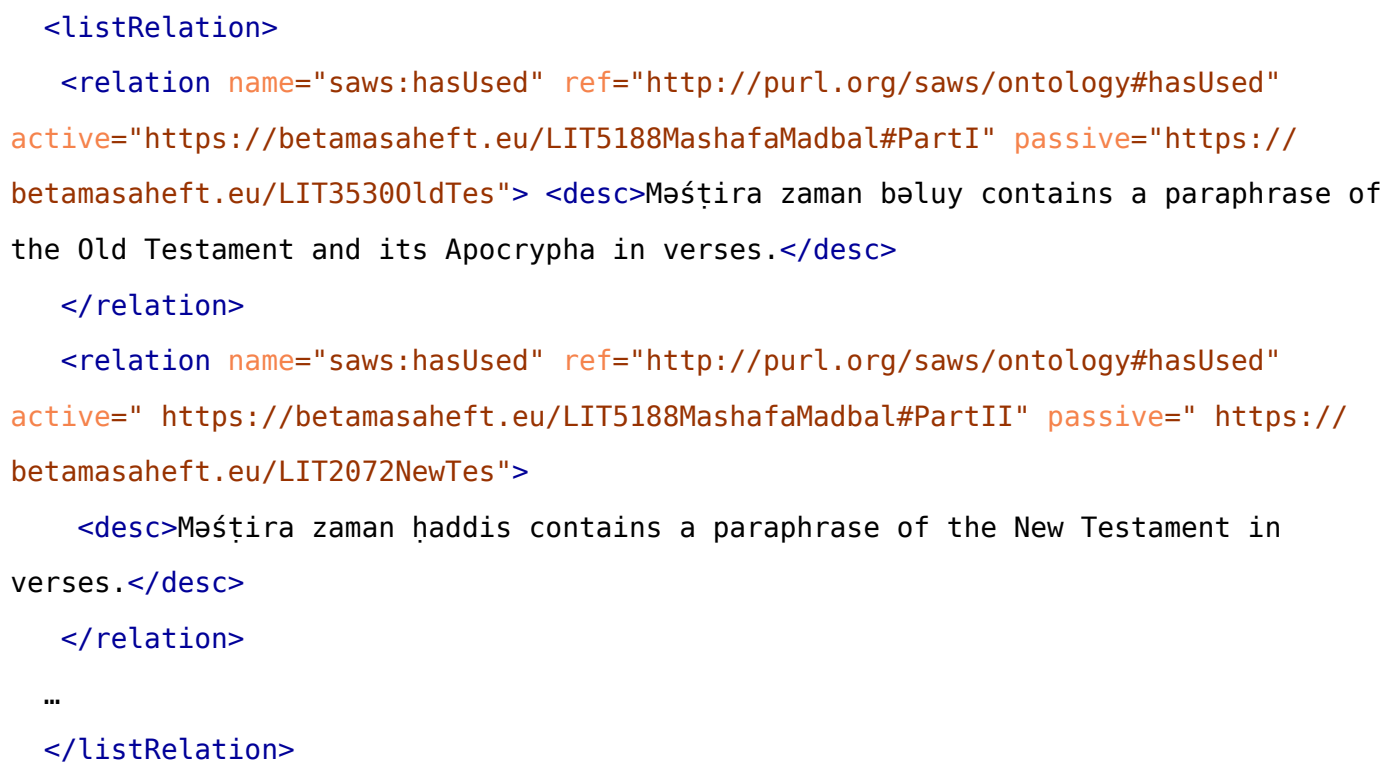

5 Further encoding of more precise relations between the single text parts of the recipient text and the source texts is also possible. In the previous example, a relation was stated between Mośțira zaman haddis and the New Testament in general. However, Məșțira zaman haddis contains a 
section clearly referring to the Four Gospels (CAe 1560) ${ }^{10}$ (part of the New Testament). This relation can be additionally encoded as in the following example, where Mośțira zaman haddis has a <div type="textpart" subtype="part" $x m l:$ lang="gez" $x m l: i d=" F o u r G o s p e l s ">$ standing for the paraphrase of the Four Gospels:

Example 2. <relation> used to document text reuse at the level of a text part.

<relation name="saws: hasUsed" ref="http://purl.org/saws/ontology\#hasUsed" active="https://betamasaheft. eu/LIT5188MashafaMadbal\#FourGospels" passive=" https://betamasaheft.eu/LIT1560Gospel">

$</$ relation $>$

6 In some cases, a particular <div type="textpart " $>$ of the recipient text can even be linked to a project identifier of a source text using a @corresp attribute. In the project Beta mașāhoft such a way of encoding is often applied to descriptions of collections containing texts with attested independent circulation. ${ }^{11}$ However, for some cases of text reuse this practice seems also to be appropriate, especially if the text contains clearly delimited verbatim quotations such as the socalled Ethiopian Psalter of the Virgin (Mazmura Dangal) (CAe 3985), ${ }^{12}$ a hymnological composition dedicated to St Mary. It consists of the Psalms of David (CAe 2000), ${ }^{13}$ the Canticles of the Prophets (CAe 1828), ${ }^{14}$ and the five sections of the Song of Songs (CAe 2362) ${ }^{15}$ (those texts constituting traditionally the Ethiopian Psalter (CAe 2701) ${ }^{16}$ ), as well as additional texts of a much later origin, ascribed to a certain monk named Mazmura Dəngal from the fifteenth century and dedicated to St Mary (which are referred to as Marian texts). ${ }^{17}$ The Marian texts consist of an opening prayer and 150 short psalms corresponding to and inspired by the Psalms of David, 15 prayers corresponding to the Canticles of the Prophets and five prayers inspired by the Song of Songs. They are usually written directly after the corresponding texts of the Psalter. The Marian texts are not attested in their independent circulation and are always combined with the corresponding texts of the Psalms of David (Sokolinskaia and Pietruschka 2007). Thus, the single sections of the Ethiopian Psalter constitute indispensable parts of the Psalter of the Virgin and represent a case of text reuse as verbatim quotations, which are well identifiable and may be clearly delimited from the Marian texts. Every psalm of the Psalter of the Virgin consists of a quotation of a Psalm of David and of a corresponding Marian text marked up with $<$ div type="textpart" $>$ s. The $<$ div 
type=" textpart ">s of the quotations can thus be linked to the corresponding Psalms of David using a @corresp attribute. As every Psalm of David has its own pointer ${ }^{18}$ a @corresp attribute points exactly to a quoted Psalm, as in the example below:

Example 3. Text reuse of the Psalter of David in the Psalter of the Virgin.

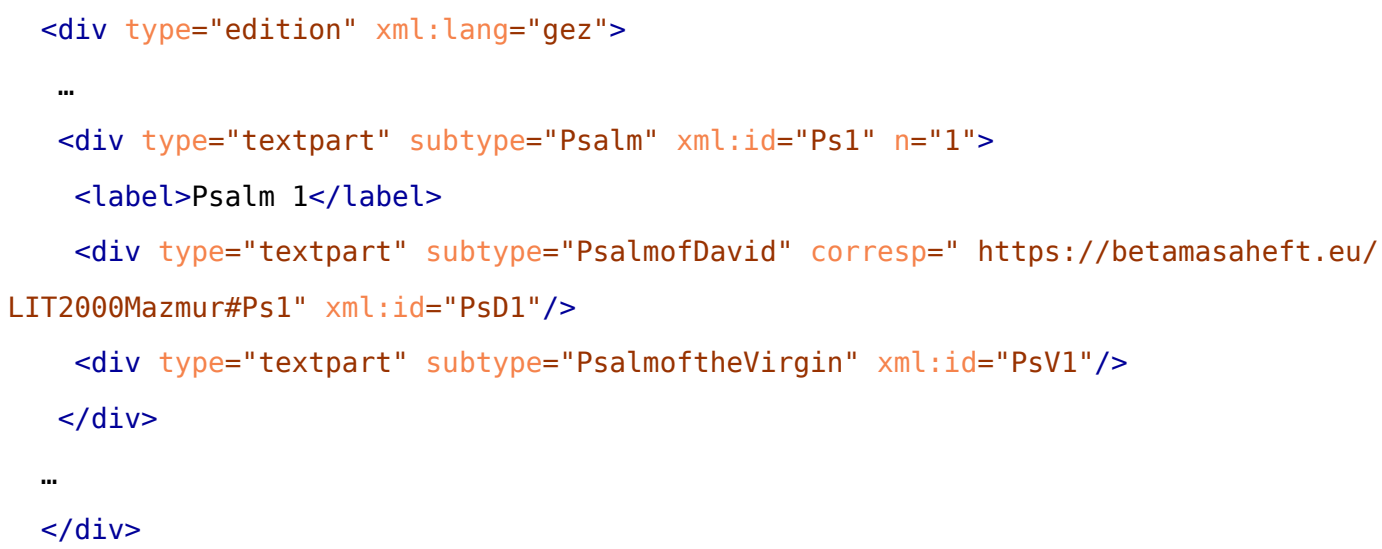

7 The process of encoding of the Psalter of the Virgin in the proposed way is the opposite to the composing of its text by a scribe, when considering how a Psalter manuscript is transformed into a Psalter of the Virgin. A scribe must add the Marian texts to the text of the Psalter, whereas the proposed encoding ideally transcludes the Psalter into a Psalter of the Virgin. ${ }^{19}$ The same is applicable to other texts, such as the Canticles of the Prophets and the Song of Songs. Here the quotations can be linked precisely to the quoted portions of text, for they correspond to the existing text divisions of the source texts:

Example 4. Text reuse of the Song of Songs in the Canticles of the Prophets.

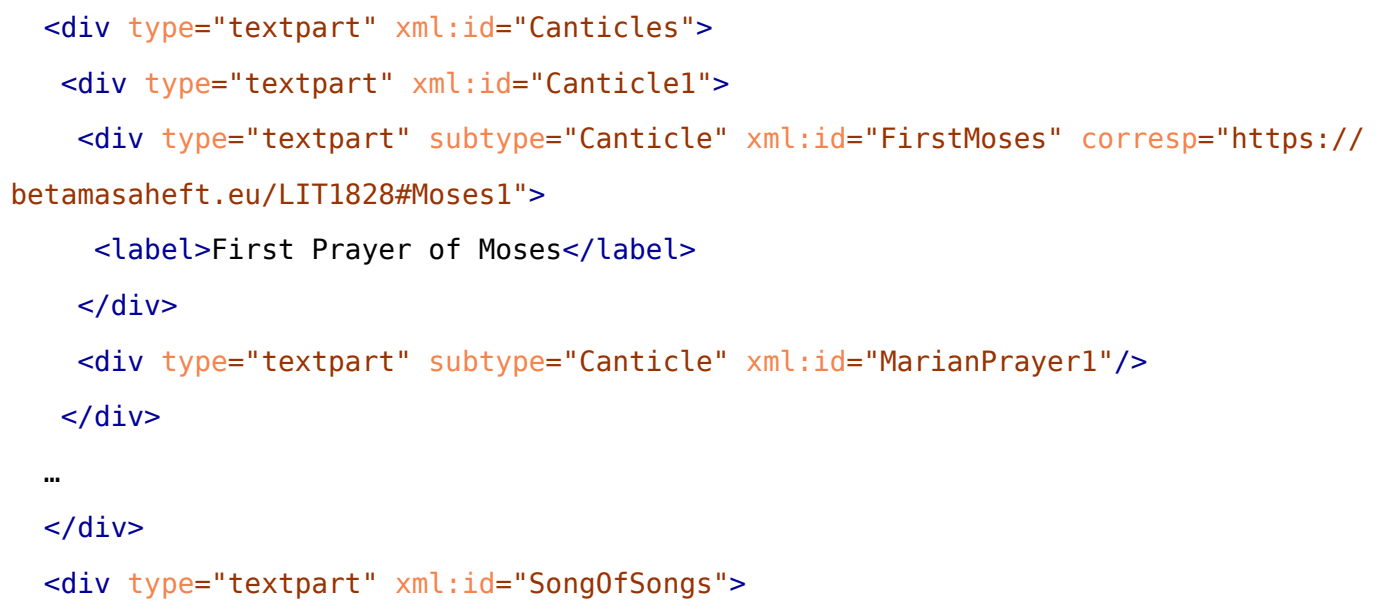




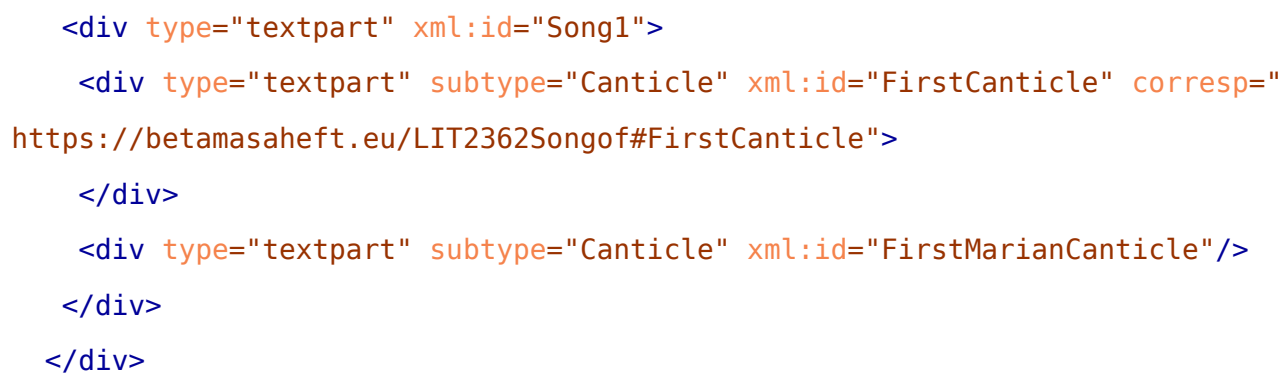

8 Additionally a relation between textual units is encoded using <relation name=" saws : contains" $>$, as those texts are always contained by the Psalter of the Virgin:

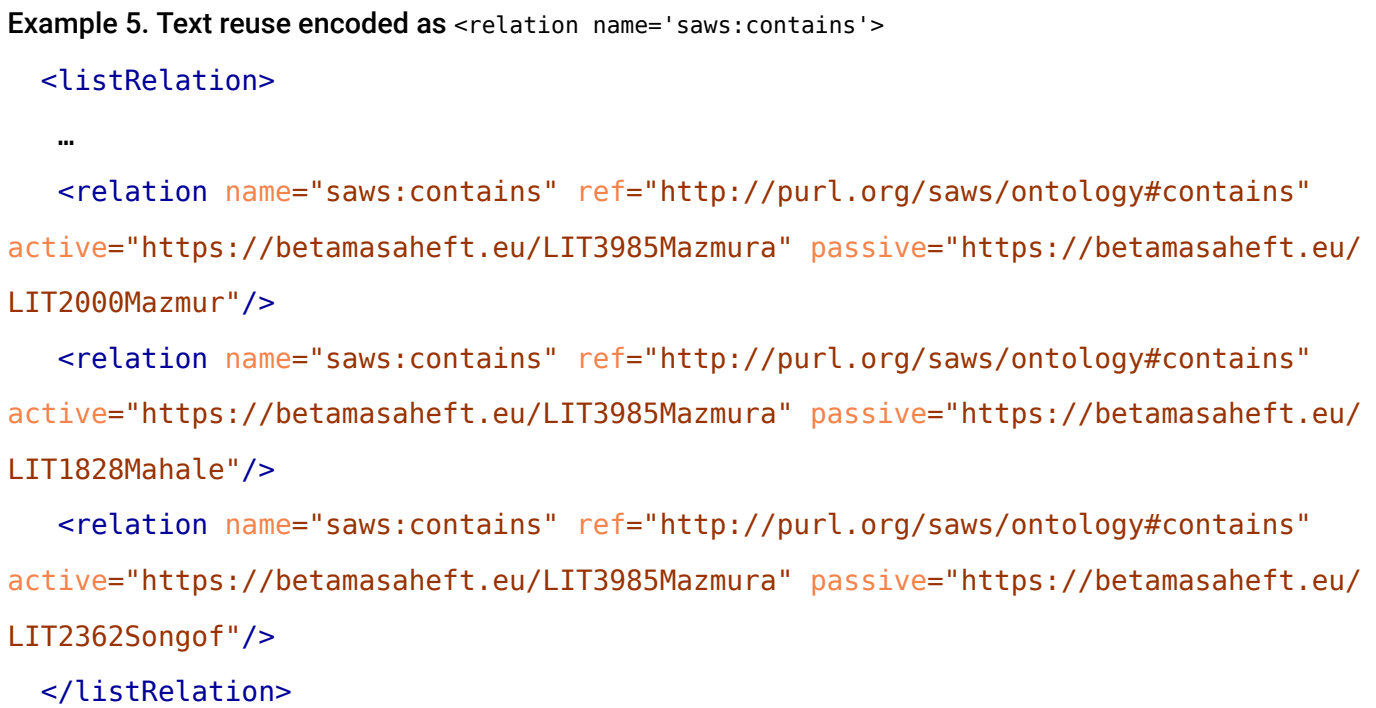

9 As already mentioned, the last method of encoding text reuse with the help of the @corresp attribute is extremely economic for it utilizes the traditional system of text divisions of the Ethiopic Bible and does not require the encoding of relations between single text parts of the source and recipient texts in <relation> elements. The source text is pointed directly in the $<$ div type=" textpart" $>$. However, this encoding practice has its limitations: firstly, the text reuse should be in form of verbatim quotations otherwise the pointing to the source text with a @corresp element would be not satisfactory; secondly, the quotation should be clearly delimited from the rest of the text; and thirdly, it presupposes the existence of the encoded structure of text which would allow the indication of particular passages by using a referencing system. In the particular case of the Psalter of the Virgin, the usage of a @corresp element seems to be the most economic and 
simple solution, ${ }^{20}$ because each psalm of David perfectly corresponds to the same psalm of David in the Psalter of the Virgin and the Psalms of David have already been encoded using corresponding $<$ div type="textpart "> ${ }^{21}$ Moreover, there is at least one example that evidences the turning of a Psalter manuscript into the Psalter of the Virgin, simply by adding Marian texts (Sokolinskaia and Pietruschka 2007).

\section{Markup of Borrowed Material}

Some examples of text reuse are slightly more complicated and the introduction of < div type="textpart">s in the recipient text, which correspond to the borrowed material, may be a legitimate practice, even if they do not belong to the traditional system of text divisions. An example is the Vita of Cyril of Alexandria (CAe 2630). ${ }^{22}$ This text, originally composed in Geez, is a compiled biography of Cyril of Alexandria based on different texts. The Vita states at its beginning that the text derives information from the Synaxarium (CAe 2375), ${ }^{23}$ Chronicle of John of Nikiu (CAe 1239), ${ }^{24}$ PAbušăkar (CAe 1011), ${ }^{25}$ and Tārika Walda 'Amid (CAe 4723). ${ }^{26}$ The portions of text based on the Synaxarium and the Chronicle of John of Nikiu are signalized, while others are not clearly identifiable at least for the time being. For the sake of brevity, only the relations between the Vita of Cyril of Alexandria and the Chronicle of John of Nikiu will be discussed. The Chronicle of John of Nikiu, the source text, is a lengthy text divided into 122 Chapters. The Vita of Cyril of Alexandria ${ }^{27}$ attests the text reuse of two of its chapters, chapter $79^{28}$ in the form of an almost verbatim quotation and chapter $87^{29}$ in the form of a quite concise paraphrase. Both cases of text reuse are signalized by a clear reference to the cited work and even to the chapter numbers.

11 In this case it appears legitimate and practical to introduce text divisions with < div type="textpart" $>$ elements in the Vita of Cyril of Alexandria which would correspond to single cases of text reuse: the quotation and the paraphrase from the Chronicle of John of Nikiu are clearly delimited from the rest of the text and it is hardly imaginable that possible alternative text divisions (for example, introduced by a future edition) would create a conflict of overlapping hierarchies, thus the borrowed material in the Vita of Cyril of Alexandria might be marked 
up with following <div type="textpart">s, where <div type="textpart" subtype="vita" xml : id="Vita0fCyril" $>$ is the Vita of Cyril of Alexandria inside the patristic collection Qerallos (CAe 3309) ${ }^{30}$ named after Cyril of Alexandria (Bausi 2010):

Example 6. <div type=' textpart ' > in the Qerəllos.

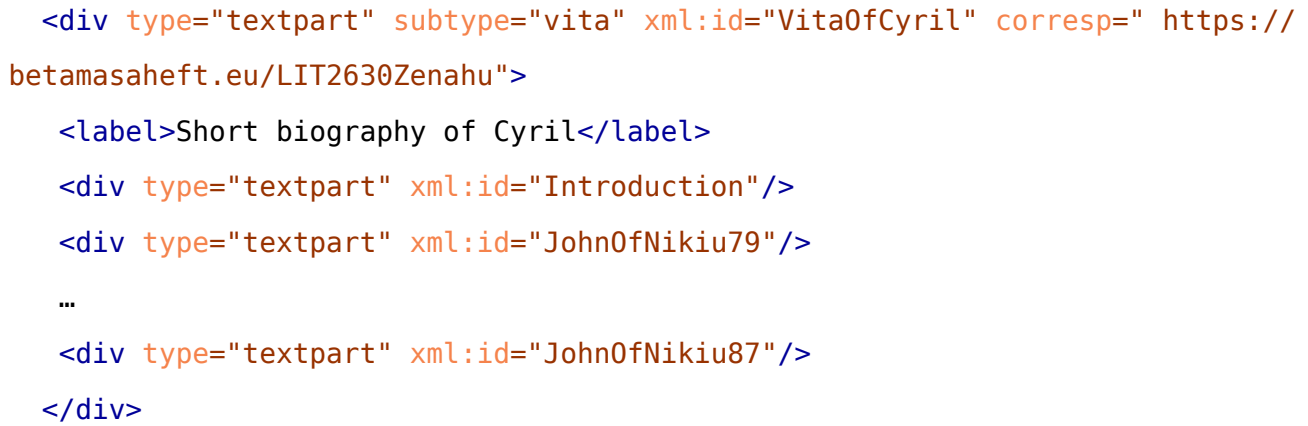

The corresponding relations to chapters 79 and 87 of the Chronicle of John of Nikiu could then be encoded as follows:

13

\section{Example 7. Text reuse of the Chronicle of John of Nikiu in the Vita of Cyril of Alexandria.}

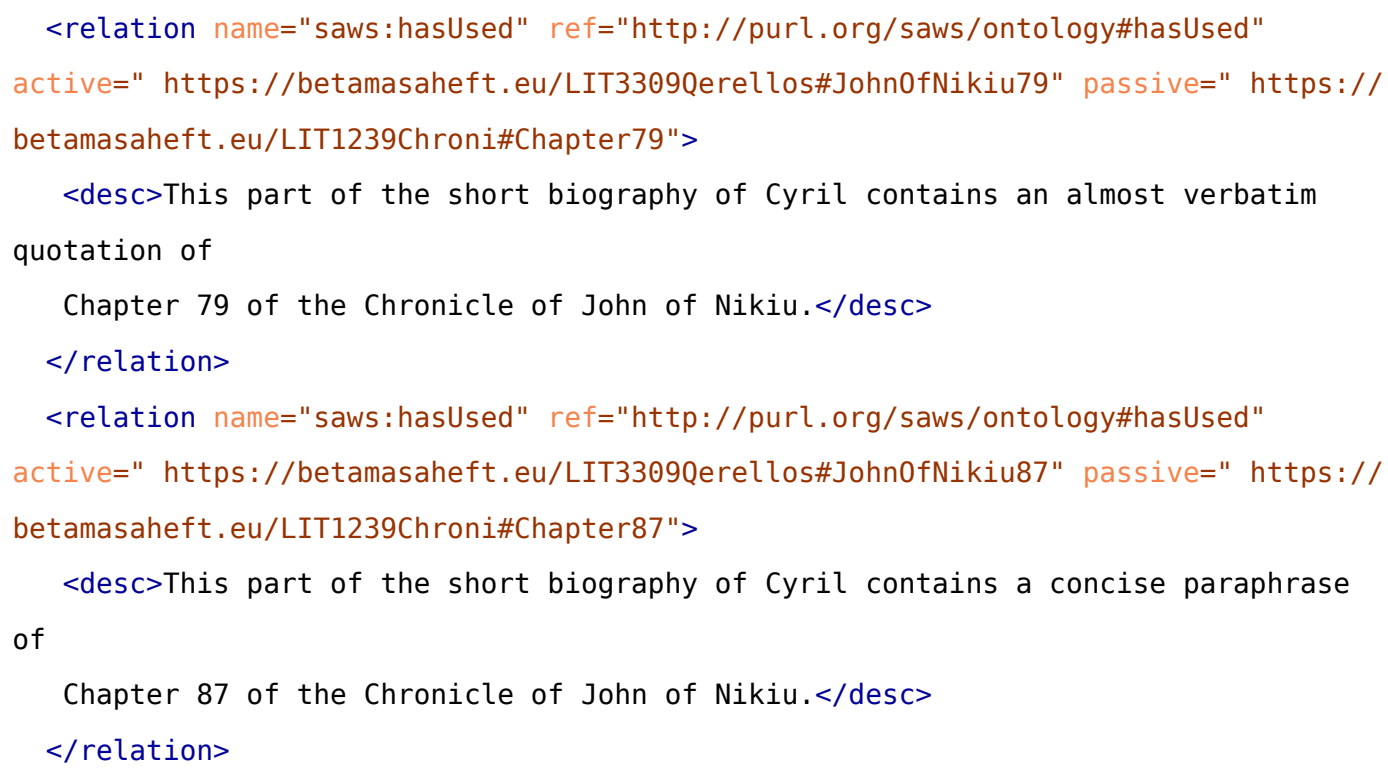


14 I have preferred to encode the first case of text reuse using a <relation name=" saws : hasUsed "> rather than a @corresp attribute as in the previous case, for two reasons. Firstly, the markedup string contains a sentence signalizing the text reuse. As I consider it to be a part of a <div type="textpart">, this < div type="textpart"> does not correspond any more precisely to chapter 79 of the Chronicle of John of Nikiu. Secondly, the text of the chapter has a small but crucial modification, which could have been introduced via scribal error or the compiler's intention. In the text of the Chronicle of John of Nikiu this chapter tells the story of St Theophilus and mentions St Cyril, his nephew, only once (Zotenberg 1883, 88-89, 315-317; Charles 1916, 75-76; Elagina 2018, 116-119). However, in the Vita of Cyril of Alexandria the name of Theophilus was substituted by the name of Cyril thus the story of Theophilus becoming a bishop becomes that of Cyril (Elagina 2018, Ixi,116-119). ${ }^{31}$ It is difficult to determine whether this innovation was the intention of the compiler of the Vita of Cyril of Alexandria or scribal error, whether in the text of the Vita of Cyril of Alexandria or its Vorlage. Despite being a small innovation in formal terms, it changes the meaning of the text completely and can represent a deep reworking of the source material. Thus, I preferred to encode it using < relation name=" saws : hasUsed " $>$ and to describe the relation more precisely in the $<$ desc $>$.

Regarding the example of the Vita of Cyril of Alexandria the possibility and added value of defining the strings of borrowed material with <div type="textpart" $>$ s may be discussed. Basically, if introducing such < div type="textpart ">s is possible and does not alter the already established system of text divisions, the markup of precise strings of borrowed material could be a sustainable practice. Especially in the case of a lengthy recipient text, which attests phenomena of sporadic text reuse, or of unsignalized hardly retrievable text reuse, the markup of borrowed material in a digital edition could be a good solution. To distinguish the markup of text reuse from other text divisions for the sake of searchability and for an adequate visualization, one can use a value "textreuse" in the @subtype attribute to signalize the specific character of the $<$ div type="textpart">s. This method of encoding could then signalize text reuse even if a corresponding < div type=" textpart "> cannot be linked with a @corresp attribute or < relation> to an internal or external identifier of a source text. ${ }^{32}$ Besides the possibility of highlighting the borrowed material in the text, this markup would provide more usable data for quantitative and qualitative analysis of the scale of text reuse in a literary work, or in a group of literary works if 
they follow the same way of encoding. For example, one could compare the strings of the borrowed material with the strings of an "innovative" text to analyze their ratio, or compare the strings of borrowed material from different sources, etc.

\section{Narrative Units and Text Reuse}

At this point the concept of narrative units is addressed, which is applied for the encoding of some other cases of parallel text transmissions in the project Beta mașāhoft. The project inherited the concept from Orlandi $(2013,93)$ and applies the definition of a narrative unit as "a unit which is only about form and general content and not one exact sequence.... While textual units (i.e., works of literature -D.E.) must have, by definition, a fixed content and a precise sequence, narrative units do not have these requirements and allow for a constructive fuzziness which enables researchers to point to an ideal text which does not have fixed contents in a fixed sequence. One practical use of this distinction is, for example, to associate narrative portions to different recensions of a text" (Liuzzo 2019, 83). Indeed, the database of the project contains by now 182 narrative units, which can be divided into two main groups: narrative units which define a specific type of a text (for example, NAR0001gwelt ${ }^{33}$ for a text of a land donation) and narrative units which refer to portions of texts which are transmitted as "different versions in multiple recensions of the same work or even in different works" (Liuzzo et al. 2018). For example, NAR0013pelican ${ }^{34}$ always indicates the portion of text on the pelican in different recensions of the Physiologus (CAe 1401) ${ }^{35}$ in Ethiopic (Villa 2018).

17 However, the concept of narrative units does not necessarily implicate the source text-recipient text relation, which is a core concept of text reuse. In case of multiple translations of a literary work, as with the Ethiopic Synaxarium, extant in two translations, Synaxarium (Group A) (CAe 4032) ${ }^{36}$ and Synaxarium (Group B) (CAe 4033) $)^{37}$ none of its translations is a source for another one, but they do share narrative units. Moreover, upon returning to the definition of text reuse at the beginning of this paper, it can be seen that the text reuse implies that a material has been borrowed "in order to serve a different purpose" (Lee 2007, 472). This is an important aspect of text reuse which means for instance, that a new text redaction which preserves the initial purpose of a text does not represent a case of text reuse, but again it shares narrative units with the previous text redaction. Thus, the narrative units are employed to document a different phenomenon: texts which might 
at least theoretically be traced back to a common (often very distant) ancestor-be it a certain text or a text model (as in the case of land grants above)-whereas the text reuse implies that the texts reveal ancestor - descendant relationships. That, however, does not mean that narrative units are completely excluded from the markup of text reuse. For example, if the source text has been lost, but its alternative versions or recensions are still attested, the recipient text can be linked to the narrative units of these versions. The same is applicable if the source text is not clearly identifiable.

\section{Linking to External Resources}

18 The last example presents a way of implicitly documenting text reuse, involving external resources. The above-mentioned Chronicle of John of Nikiu, quoted and paraphrased in the Vita of Cyril of Alexandria, is itself dependent on several sources. This historiographical text was written around the end of the seventh century in Egypt by John, an Egyptian bishop. The original of the Chronicle of John of Nikiu was compiled either in Greek or in Coptic. Around the twelfth century the text was translated into Arabic and transmitted into Ethiopic at the beginning of the seventeenth century. The Ethiopic version is the only surviving version of this text at the current state of the knowledge. The first part of the Chronicle of John of Nikiu apparently relies on several sources and shows parallels with a number of other texts (Zotenberg 1883, 9-10; Charles 1916, xi-xii; Carile 1986, 362-363). As the text belongs to the genre of a universal chronicle the author had to rely on already existing textual traditions to describe the events prior to his time. Thus, the Chronicle of John of Nikiu attests numerous cases of text reuse which could be marked up and linked to the available parallel traditions, which however had not necessarily been the direct sources for the Chronicle of John of Nikiu. One such tradition is the Chronicle of John Malalas, which is the earliest extant example of a Byzantine chronicle (E. Jeffreys, M. Jeffreys, and Scott 1986, xxi-xxiii). The similarities between these two texts are so striking that the Chronicle of John of Nikiu is even included in the list of the witnesses to the Chronicle of John Malalas (E. Jeffreys, M. Jeffreys, and Scott 1986, xxvi) ${ }^{38}$ Currently a digital edition of the Chronicle of John Malalas ${ }^{39}$ and a philological and historical commentary are the focus of the project of the Heidelberger Akademie der Wissenschaften, held at the Universität Tübingen. ${ }^{40}$ The text, which is partially available on-line, is visualized according to the books and chapters of the Chronicle of John Malalas, each of the chapters having its own URL. The encoding practice of the project Beta mașähəft allows for the linking of a particular work or its 
single $<$ div type=" textpart" $>$ s to external entries using $<$ relation name=" skos : exactMatch" $>$ ${ }^{41}$ or $<$ relation name="skos: broadMatch" $>{ }^{42}$ Regarding the relations between the Chronicle of John of Nikiu and the Chronicle of John Malalas the application of <relation name="skos: broadMatch"> within the project's Guidelines seems to be a legitimate option. Thus, for example, chapter 4 of the Chronicle of John of Nikiu attests parallels with Book 1.5 of the Chronicle of John Malalas. ${ }^{43}$ Therefore, it can be encoded as in example 8 .

\section{Example 8. Parallel transmission of the Chronicle of John of Nikiu in the Chronicle of John Malalas.}

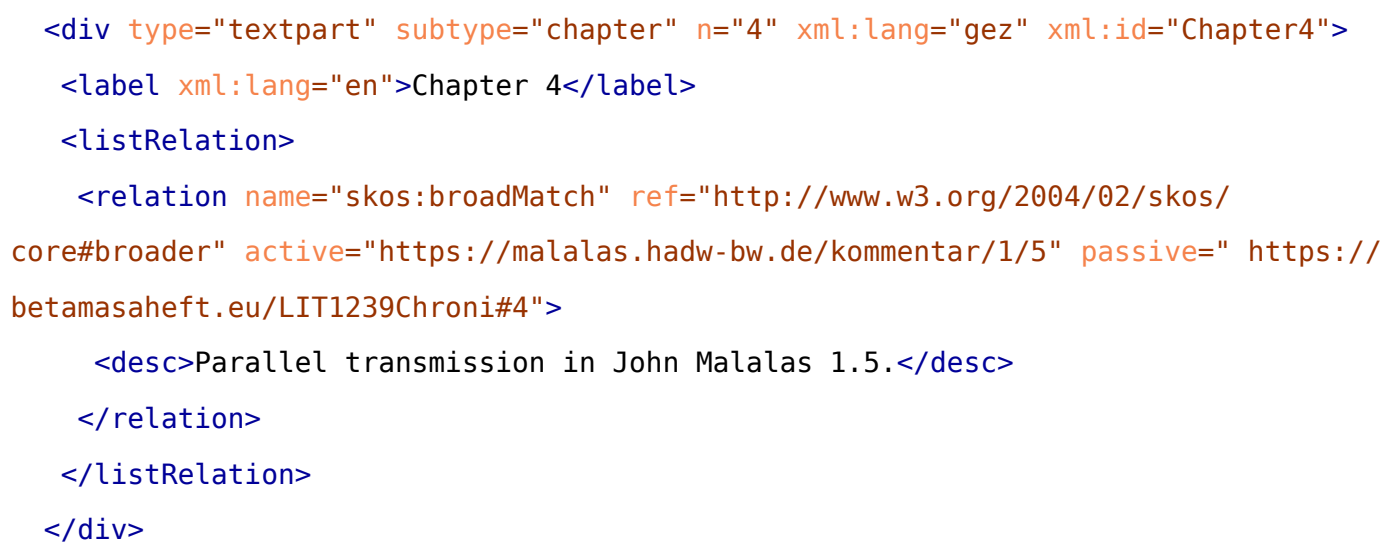

19 This is rather an implicit and economic way of encoding text reuse. The similarities between the Chronicle of John Malalas and the Chronicle of John of Nikiu attest the case of text reuse in the Chronicle of John of Nikiu, however, they do not directly point to the Chronicle of John Malalas as a source text. ${ }^{44}$ It is important to note here also that the text reuse took place at the stage of the production of the original text of the Chronicle of John of Nikiu, in Egypt, in Coptic or Greek, but not in Ethiopic language. Therefore, in this case the text reuse is not documented for the manuscript culture of Ethiopia and Eritrea but rather for the Coptic or Copto-Greek manuscript culture, in which the original was produced.

\section{Conclusion}

Text reuse is an interesting aspect of literary traditions, which opens wide perspectives for future studies. Its detection and documentation may help a deeper understanding of a given written culture. In this paper I attempted to address the existing approaches and possibilities of encoding 
the text reuse in the project Beta mașāhoft. The variety of forms of text reuse is reflected in the variety of possibilities of its encoding, ranging from exact mapping of the relation between target text and the source text to a more fluid descriptive markup. The article has addressed several problems faced in the encoding of text reuse: the mapping of the source and the recipient texts, the markup of the strings of borrowed material, the encoding of text reuse of a different manuscript tradition within the frame of the project. The strategies of encoding the single cases presented in the paper may certainly be criticized and improved, however, they seem to satisfy the basic academic needs. Nevertheless, a more standardized approach to the encoding of text reuse might deliver better data for statistical approaches at the level of a single work, the literary production of a particular period or of the tradition in general.

\section{BIBLIOGRAPHY}

Bausi, Alessandro. 2010. "Qerəllos." In Encyclopaedia Aethiopica, edited by Siegbert Uhlig and Alessandro Bausi, IV:287a-90. Wiesbaden: Harrassowitz Verlag.

Monica Berti, Bridget Almas, David Dubin, Greta Franzini, Simona Stoyanova and Gregory R. Crane. 2015. "The Linked Fragment: TEI and the Encoding of Text Reuses of Lost Authors," Journal of the Text Encoding Initiative 8 http://journals.openedition.org/jtei/1218, doi:10.4000/jtei.1218.

Carile, Antonio. 1986. “Giovanni Di Nikius: Cronista Bizantino-Copto Del VII Secolo.” In Byzantium: Tribute to Andreas N. Stratos, II: Theology and Philology: 353-98. Athens.

Charles, Robert Henry. 1916. The Chronicle of John, Bishop of Nikiu Translated from Zotenberg's Ethiopic Text. Text and Translation Society London: Williams \& Norgate. https://archive.org/details/ CharlesTheChronicleofJohnBishopOfNikiuTranslatedFromZotenbergsEthiopicText/.

Colin, Gérard, and Alessandro Bausi. 2010. “Sənkəssar." In Encyclopaedia Aethiopica, edited by Siegbert Uhlig and Alessandro Bausi, IV:621a-23. Wiesbaden: Harrassowitz Verlag.

Elagina, Daria. 2018. "The Textual Tradition of the Chronicle of John of Nikiu: Towards the Critical Edition of the Ethiopic Version.” Hamburg: Universität Hamburg. https://ediss.sub.uni-hamburg.de/handle/ ediss $/ 6331$.

Franzini, Greta, Emily Franzini, and Marco Büchler. 2016. “Historical Text Reuse: What Is It?” 2016. http:// www.etrap.eu/historical-text-re-use/.

Journal of the Text Encoding Initiative, Issue rolling, 22/01/2022 
Jeffreys, Elizabeth, Michael Jeffreys, and Roger Scott, trans. 1986. The Chronicle of John Malalas. Vol. 4. Byzantina Australiensia. Melbourne: Australian Association for Byzantine Studies.

Lee, John. 2007. “A Computational Model of Text Reuse in Ancient Literary Texts." In Proceedings of the 45th Annual Meeting of the Association of Computational Linguistics, edited by Annie Zaenen and Antal van den Bosch, 472-479. Prague: Association for Computational Linguistics. https://aclanthology.org/ P07-1060.pdf.

Liuzzo, Pietro Maria. 2019. Digital Approaches to Ethiopian and Eritrean Studies. Supplement to Aethiopica 8. Wiesbaden: Harrassowitz Verlag. https://doi.org/10.2307/j.ctvrnfr3q.

Liuzzo, Pietro Maria, Dorothea Reule, Eugenia Sokolinski, Solomon Gebreyes, Daria Elagina, Denis Nosnitsin, Eliana Dal Sasso, and Jacopo Gnisci. 2018-. Beta Maṣāḥft Guidelines. https://betamasaheft.eu/Guidelines/. Orlandi, Tito. 2013. “A Terminology for the Identification of Coptic Literary Documents," Journal of Coptic Studies, no. 15: 87-94. doi:10.2143/JCS.15.0.3005414.

Pietruschka, Ute. 2005. “Giyorgis Wäldä 'Amid.” In Encyclopaedia Aethiopica, edited by Siegbert Uhlig, II:812b14. Wiesbaden: Harrassowitz Verlag.

Raineri, Osvaldo. 2005. Salmi Etiopici Di Cristo e Della Vergine. Roma: Appunti di Viaggio.

Sokolinskaia, Evgenia, and Ute Pietruschka. 2007. “Mäzmurä Dəngəl.” In Encyclopaedia Aethiopica, edited by Siegbert Uhlig, III:896b-97. Wiesbaden: Harrassowitz Verlag.

Ternès, Anabel. 2016. Intertextualität: Der Text Als Collage. Wiesbaden: Springer.

Thurn, Ioannes, ed. 2000. Ioannis Malalae Chronographia. Vol. 35. Corpus Fontium Historiae Byzantiae. Berlin: Walter de Gruyter.

Uhlig, Siegbert. 2003. "Abušakər." In Encyclopaedia Aethiopica, edited by Siegbert Uhlig, I: A-C:56b-57b. Wiesbaden: Harrassowitz Verlag.

Villa, Massimo. 2018. "Encoding Strategies and the Ethiopic Literary Heritage: The Physiologus as a Case Study." Comparative Oriental Manuscript Studies Bulletin 4/1 Linking Manuscripts from the Coptic, Ethiopian and Syriac Domain: Present and Future Synergy Strategies: 143-50. doi:10.25592/uhhfdm.271.

Weninger, Stefan. 2007. “John of Nikiu.” In Encyclopaedia Aethiopica, edited by Siegbert Uhlig, III:298a-99. Wiesbaden: Harrassowitz Verlag.

Wright, William. 1877. Catalogue of the Ethiopic Manuscripts in the British Museum Acquired since the Year 1847. Piccadilly, Covent Garden-Berlin: Longmans \& CO., Asher \& CO. https://archive.org/details/ catalogueofethio0obrituoft. 
Zotenberg, Hermann. 1883. Chronique de Jean, évêque de Nikiou: texte éthiopien. Edited and translated by Hermann Zotenberg. Extrait des Notices des Manuscrits 24/1. Paris: Imprimerie nationale. http:// catalogue.bnf.fr/ark:/12148/cb30650253k.

\section{NOTES}

1 The term intertextuality was coined by Julia Kristeva and is applied now to a broad range of theories on relations between texts. Here I quote a brief explanation by Anabel Tèrnes on the basic difference between the traditional and intertextual approach of Kristeva: "Die traditionelle Forschung $z u$ den Beziehungen zwischen Texten geht davon aus, dass der zitierende Text sich der Textelemente eines fremden Textes bedient, d.h. sie in seine Struktur integriert, während der zitierte Text von diesem Prozess unangetastet bleibt. Das Zitat erhält seinen Sinn durch den es umgebenden neuen Kontext. Im Gegensatz dazu gehen Kristeva und die mit ihr assoziierten Literaturkritiker der Gruppe Tel Quel davon aus, dass erst der Dialog, die Verweisungsmechanismen zwischen Text und Prätext den Sinn beider Texte konstituieren. Textsinn ist demnach Effekt eines Textspielverfahrens. Die telquelistische Texttheorie geht insofern über die klassische Konzeption der Literatur hinaus, als für sie der Sinn keine Gegebenheit ist, die nur noch mittels einer instrumentalen Zeichenstruktur darzustellen wäre, sondern Sinn wird im Text erzeugt, und zwar durch Transformation, Auflösung, Be- und Verarbeitung bereits bestehenden Sinns, der immer in Textform vorliegt. Ein anderer Name für diese Auffassung von Sinnproduktion ist der Begriff Intertextualität." (Ternès 2016, 13-14)

2 The project Beta mașāhəoft: Manuscripts of Ethiopia and Eritrea (Schriftkultur des christlichen Äthiopiens: eine multimediale Forschungsumgebung) is a long-term project funded within the framework of the Academies' Programme (coordinated by the Union of the German Academies of Sciences and Humanities) under survey of the Akademie der Wissenschaften in Hamburg. The goal of the project is the establishment of a multi-media research environment for the study of the manuscript culture of Ethiopia and Eritrea. For the project's website visit: accessed January 23, 2022, https:// www.betamasaheft.uni-hamburg.de/about.html. For the project's web application visit: accessed January 23, 2022, https://betamasaheft.eu/. See Liuzzo 2019.

3 Some encoding examples were presented in September 2019 at the poster session of the 2019 TEI Conference "What is text, really? TEI and beyond" at University of Graz in Austria under the title "Case Study for Encoding: Ethiopian Psalter of the Virgin." 
4 Accessed January 23, 2022, https://betamasaheft.eu/Guidelines/?id=general.

5 Overlapping hierarchies represent two or more coexisting structures in one document, which interact in a non-hierarchical way. As a result, a document cannot be represented as a tree graph.

6 This relation saws:hasUsed is part of the ontology of the project Sharing Ancient WisdomS (SAWS), accessed January 23, 2022, https://ancientwisdoms.ac.uk/, and reflects a relation between a Person (an author) and the Original Material (transcription of a text produced by a scribe). See, accessed January 23, 2022, https://ancientwisdoms.ac.uk/media/ontology/ SAWS_relationship_types.html. However, within the project Beta mașāḩft the relation is applied to encode a text reuse in very generic way. See, accessed January 23, 2022, https://betamasaheft.eu/ Guidelines/?id=relations. As the authorship of most Ethiopian literary works (especially those which have been originally produced in Ethiopia or Eritrea) is unknown, this application might be legitimate.

7 Accessed January 23, 2022, https://betamasaheft.eu/LIT5188MashafaMadbal .

8 Accessed January 23, 2022, https://betamasaheft.eu/LIT35300ldTes.

9 Accessed January 23, 2022, https://betamasaheft.eu/LIT2072NewTes.

10 Accessed January 23, 2022, https://betamasaheft.eu/LIT1560Gospel.

11 See, accessed January 23, 2022, https://betamasaheft.eu/Guidelines/?id=definitionWorks.

12 Accessed January 23, 2022, https://betamasaheft.eu/LIT3985Mazmura .

13 Accessed January 23, 2022, https://betamasaheft.eu/LIT2000Mazmur.

14 Accessed January 23, 2022, https://betamasaheft.eu/LIT1828Mahale.

15 Accessed January 23, 2022, https://betamasaheft.eu/LIT2362Songof.

16 Accessed January 23, 2022, https://betamasaheft.eu/LIT2701Dawit.

17 For the translation of Marian texts see also Raineri 2005, 133-187.

18 For example, the short-form URIs used in the examples in this paper "https://betamasaheft.eu/ LIT2000Mazmur\#Ps1" considers the URI https://betamasaheft.eu/LIT2000Mazmur as base of a graph where Ps1 identifies an entity corresponding to the element (<div> in this case) and its axml:id. These short URIs are used in the data and can be resolved to a URL like https://betamasaheft.eu/works/LIT2000Mazmur/text\#Ps1, https://betamasaheft.eu/LIT2000Mazmur.Ps1, or accessed January 23, 2022, https:// betamasaheft.eu/LIT2000Mazmur.1, all of which map to a parametrized URL of the 
format https://betamasaheft.eu/works/LIT2000Mazmur/text?ref=Ps1 calling a Distributed Text Services (DTS) compliant Endpoint for https://betamasaheft.eu/api/dts/document?id=https:// betamasaheft.eu/LIT2000Mazmur\&ref=Ps1. For DTS see, accessed January 23, 2022, https:// distributed-text-services.github.io/specifications/.

19 This is what the application does with the markup, that is fetch the text from @corresp for the view.

20 In case of literal quotations, the Guidelines of the project allows also for encoding them using $<$ cit $>$ containing < quote $>$ and the $<$ ref $>$ pointing to the source text. See, accessed January 23, 2022, https://betamasaheft.eu/Guidelines/?id=referencing-the-text. In this case also the quotation should correspond precisely to a < div type="textpart " > of the source text.

21 Alternatively, it is possible to use a reference system to point to corresponding string of reused material.

22 Accessed January 23, 2022, https://betamasaheft.eu/LIT2630Zenahu.

23 Accessed January 23, 2022, https://betamasaheft.eu/LIT2375Synaxa. A hagiographic compilation, for more details see Colin and Bausi 2010.

24 Accessed January 23, 2022, https://betamasaheft.eu/LIT1239Chroni. A historiographical work composed in the seventh century in Egypt, for more details see Weninger 2007.

25 Accessed January 23, 2022, https://betamasaheft.eu/LIT1011Abusak. A chronological treatise composed in the thirteenth century, for more details see Uhlig 2003.

26 Accessed January 23, 2022, https://betamasaheft.eu/LIT4723TarikaWaldaAmid. A universal chronicle composed in the thirteenth century, which was translated into Ethiopic and augmented by local accounts. For more details see Pietruschka 2005.

27 In the absence of an edition of that text, I refer here to the manuscript "Däbrä Dammo 'Abuna 'Arägawi, Ethio-SPaRe, DD-026," ff. 3r-6v, catalogued as Abreham Adugna, Denis Nosnitsin, Pietro Maria Liuzzo, Magdalena Krzyzanowska, "Bəhẹēwi Kəlləlāwi Mangəśti Təgrāy, Dabra Dāmmo 'Abuna 'Aragāwi, DD-026," in Die Schriftkultur des christlichen Äthiopiens und Eritreas: Eine multimediale Forschungsumgebung / Beta mașāḥft, edited by Alessandro Bausi, accessed August 4, 2021, https:// betamasaheft.eu/ESdd026.

28 For example, Däbrä Dammo 'Abuna 'Arägawi, Ethio-SPaRe, DD-026, fol. 3ra.

29 For example, Däbrä Dammo 'Abuna 'Arägawi, Ethio-SPaRe, DD-026, fol. 5va. 
30 Accessed January 23, 2022, https://betamasaheft.eu/LIT3309Qerellos.

31 Däbrä Dammo 'Abuna 'Arägawi, Ethio-SPaRe, DD-026, fol. 3vb.

32 With internal I understand the identifiers of the project Beta mașāhoft, while the "external" identifiers designate those applied in other projects.

33 Accessed January 23, 2022, https://betamasaheft.eu/narratives/NAR0001gwelt.

34 Accessed January 23, 2022, https://betamasaheft.eu/narratives/NAR0013pelican.

35 Accessed January 23, 2022, https://betamasaheft.eu/works/LIT1401Physio.

36 Accessed January 23, 2022, https://betamasaheft.eu/works/LIT4032SenkessarS.

37 Accessed January 23, 2022, https://betamasaheft.eu/works/LIT4033SenkessarS.

38 However, pointing that "John of Nikiu is rarely of independent value as a witness to Malala's text" (E. Jeffreys, M. Jeffreys, and Scott 1986, xxxvi).

39 Based on the edition by Thurn (2000).

40 Accessed January 23, 2022, https://malalas.hadw-bw.de/.

41 SKOS stands for Simple Knowledge Organization System, a W3C recommendation for structured controlled vocabularies (https://www.w3.org/2004/02/skos/), skos : exactMatch and skos:broadMatch are SKOS mapping properties, used to state alignment between concept in different concept schemes.

42 See, accessed January 23, 2022, https://betamasaheft.eu/Guidelines/?id=work-teiHeader. The application of this relation in the project implies according to its definition by SKOS that the passage is seen rather as a concept. But since the relations skos : exactMatch and skos : broadMatch are used to link to entities in external databases, that is most probably to the passages in other languages, referring to the interrelated passages as concepts seems reasonable.

43 Accessed January 23, 2022, https://malalas.hadw-bw.de/kommentar/1/5.

44 Alternatively, this case could also imply a markup using narrative units for portions of the Chronicle of John of Nikiu for which parallel traditions are attested. 


\section{AUTHOR}

\section{DARIA ELAGINA}

Daria Elagina is Principal Investigator of the project "The Chronicle of John of Nikiu: Text-Critical edition and Digital Research Platform" at the University of Hamburg, funded by the Deutsche Forschungsgemeinschaft (DFG, German Research Association) - 470097824. Her main research areas are textual criticism, manuscriptology, and sphragistics. 